\title{
UNPUBLISHED LETTER TO FEDERICO GARCÍA LORCA FROM CAMPBELL HACKFORTH-JONES
}

\author{
Roger Tinnell (Emeritus Professor) \\ Plymouth State University/U. System of New Hampshire
}

\begin{abstract} Cuba at the end of his 1929-1930 American trip respondence, María Antonieta Rivas, photographs.

\section{CARTA INÉDITA A FEDERICO GARCÍA LORCA \\ DE CAMPBELL HACKFORTH-JONES}

This essay provides an unpublished letter from the young Englishman Campbell (Colin) Hackforth-Jones to the poet Federico García Lorca whom he met in Granada and reencountered in New York.The essay also provides photographs of Hackforth-Jones, of García Lorca's mutual friend in New York, Maria Antonieta Rivas and of Lorca with friends in

Keywords: Federico García Lorca, Campbell (Colin) Hackforth-Jones, Unpublished cor-

\section{RESUMEN}

Este ensayo presenta una carta inédita que el joven inglés Campbell (Colin) HackforthJones le mandó al poeta Federico García Lorca a quien conoció en Granada y volvió a ver en Nueva York. El ensayo da también fotografías de Hackforth-Jones y García Lorca, de su mutua amiga en Nueva York, María Antonieta Rivas y de Lorca con amigos en Cuba al final de su viaje a América en 1929-1930.

Palabras clave: Federico García Lorca, Campbell (Colin) Hackforth-Jones, correspondencia inédita, María Antonieta Rivas, fotografías.

DOI: https://doi.org/10.25145/j.recaesin.2019.79.09

Revista Canaria de Estudios Ingleses, 79; November 2019, pp. 147-159; ISSN: e-2530-8335 
The young Englishman Campbell (aka "Colin") Hackforth-Jones (19041988), a student of Spanish at Oxford University, was awarded in 1926 a scholarship to study in Spain (his university sought to establish an exchange program with the city of Granada). On his trip south, in a Paris night club in Montmarte, HackforthJones befriended two Spaniards who soon later (during the Christmas holidays of 1926-1927) introduced him to Federico García Lorca in the poet's hometown of Granada where "Colin" also met Federico's brother Francisco ("Paco") García Lorca. Hackforth-Jones had been active in Oxford's Dramatic Society and made instant friends with the gregarious poet and dramatist Lorca. ${ }^{1}$ The poet dedicated to this new English friend the poem "Flor" published in his book Canciones (Obra completa, I. Poesia, 389) ${ }^{2}$ :

\author{
"Flor" \\ A Colin Hackforth \\ El magnífico sauce \\ de la lluvia, caía. \\ ¡Oh la luna redonda \\ sobre las ramas blancas!
}

In 1927 Lorca recommended the Oxfordian to his friend José Bello in Madrid:

Este joven es un chico inglés muy simpático estudiante de Oxford que ha estado pensionado en la Universidad de Granada. Como es escritor en seguida hemos hecho una gran amistad. Yo te ruego le acompañes y pasees con él. Seguramente te dirá cosas divertidas. Podríamos bien nombrarlo nuestro representante en Oxford pero eso lo haremos después. No ha querido conocer a nadie de literatos más que a ti [...]. Él te dará noticias mías [...]. Sé simpático con Hackforth-Jones. Llámalo Colin. Y los pocos días de su estancia en Madrid está fino con él porque con él yo lo he pasado muy bien en su compañía (Epistolario completo, 421).

Hackforth-Jones and García Lorca coincided in 1929 in New York where Lorca was enrolled in Columbia University and Hackforth-Jones was working on Wall Street for Beverly Bogarty \& Co. ("se encontraba en Nueva York en aquella época porque su padre, un bolsista próspero, le había enviado allí para trabajar en la oficina de sus agentes asociados y familiarse con sus trámites" (Epistolario completo, 637). In a letter (end of June 1929) to his family, Lorca writes about encountering "Colin Hackforth" in New York:

1 Much information in this essay was cordially given to me by Campbell Hackforth-Jones's daughter Laila Hackforth-Jones. Of great importance too is the information found in the two essays by Andrew A.Anderson, 1985 \& 2013.

2 The book Canciones was published in Málaga in 1927 (Litoral, Primer Suplemento, Imprenta Sur). A second edition was published in Madrid in 1929 (Revista de Occidente). 

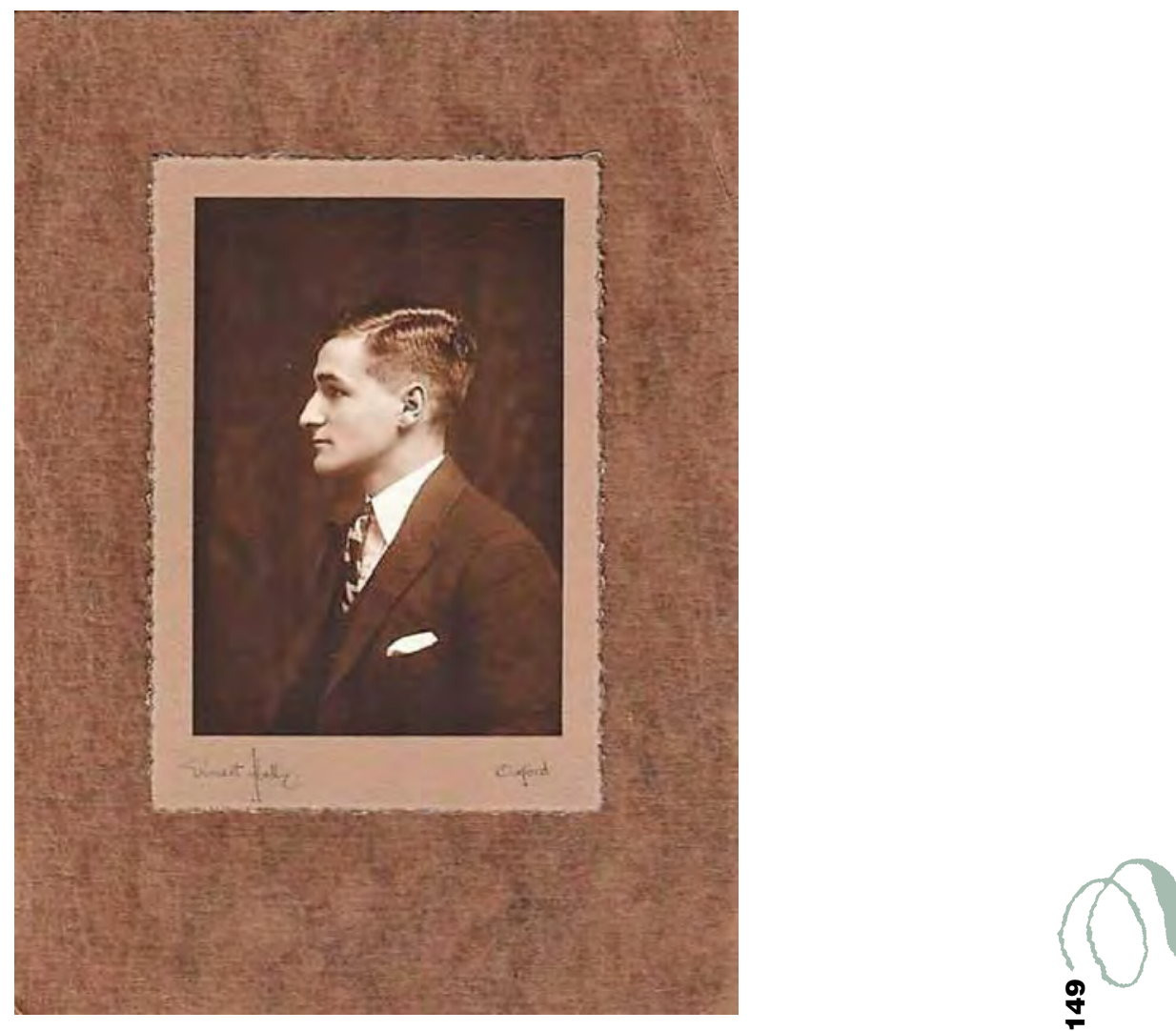

Campbell (Colin) Hackforth-Jones.

Photograph in collection of Laila Hackforth-Jones.

[D]e una ventana de un gran restaurante sale una voz grande que dice 'Federico, Federico', y veo a un muchacho que con un jersey rojo de seda da un salto, se tira a la calle con riesgo de romperse una pierna, y me abraza. Era el inglés Colin Hackforth que estuvo en Granada, y se hizo tan íntimo amigo mío [...]. He tenido realmente suerte, pues Colin es escritor y muy bueno, será realmente mi mejor maestro de inglés. Todos los días a las seis, vendrá a la Universidad y traduciremos cosas. Anoche mismo ya me hacía todas las indicaciones en lengua inglesa y me enseñaba multitud de palabras [...] no tendré más remedio que ir avanzando en el idioma y Colin me buscará un francés para cambiar conversación (Epistolario completo. 617).

\section{The Hispanist and Lorca biographer Ian Gibson writes:}

What Lorca did not tell his parents was that, when passing through London he had sent a telegram to Campbell, hoping to see him there. But the bird had flown, and the lad's parents forwarded the message to New York. Hackforth-Jones, apprised 
of the poet's imminent arrival, was therefore on the look-out for his friend. But for all that it had certainly been a rare coincidence. Campbell lived in a rented flat near $70^{\text {th }}$ Street and for several weeks Lorca visited him there, drinking his contraband gin and chatting to him and his sister Phyllis. The poet enthusiastically told his parents that his friend was going to give him English classes, but no such arrangement ensued (Gibson, 1989: 249-250).

In another letter (second week of August1929) from New, Lorca again writes his family: "Esta mañana he estado tomando el desayuno con mi amigo Colin en el Wall Street, que es el sitio de los negocios, donde está la Bolsa, los bancos y los grandes oficinas de las oficinas" (Epistolario completo, 637). Ian Gibson writes: "Al poco tiempo de llegar a Nueva York, Federico, de la mano de su amigo Campbell Hackforth-Jones, había conocido Wall Street y la Bolsa -entonces eufórica-, y describió para su familia, en la segunda semana de agosto, una de susvarias visitas con el inglés al barrio financiero de la metrópoli” (http://www.epdlp.com/texto. php?id2=9521).

In late November 1929 Campbell Hackforth-Jones returned to England and did not see again his friend García Lorca. Andrew A. Anderson writes that Hackforth-Jones was very moved by García Lorca's death, supported the Republican cause, and carefully kept the material testimony of his friendship with the Spanish poet, volumes dedicated to him by Lorca as well as drawings and photographs (Anderson, 2013: 201) ${ }^{3}$.

We find in the archives of the Centro Federico García Lorca the first page of an unpublished letter sent in 1932 to the poet from Hackforth-Jones. ${ }^{4}$ We do not know if Lorca answered this letter from Campbell Hackforth-Jones.

See here below the transcription of this previously unpublished and here unedited letter with grammatical errors in Spanish uncorrected:

Arkley House,

Barnet,

Herts $^{5}$

Agosto 24, 1932

3 The Hackforth-Jones family generously decided to donate the "H-J collection" to the Centro Federico García Lorca (email to me from Laila Hackforth-Jones, 19 August 2018).

4 The letter is unsigned and apparently incomplete (a second page has been lost?). My thanks to the heirs of Campbell Hackforth-Jones and of Federico García Lorca for permission to publish this letter which is listed with reference number $M$-Lorca COA-464 in the catalogue of Christian de Paepe, 2003, p. 236. In this same catalogue, with reference number M-Lorca COA463, p. 236, a greeting card sent to García Lorca by Hackforth-Jones (end of December 1931?). The card with printed legend To Wish dear Grandpa a Happy Birthday: "Este es para todo el mundo... es una ilustración de como pasaba yo mi juventud".

5 Thanks to the staff of the Local Studies Centre, Herndon Library, The Burroughs London, for their help and email (26 July 2018) in which they informed me that the occupant at this address was Frank William Hackforth-Jones J.P. On Frank William Hackforth-Jones, Campbell's father, see https://search.livesofthefirstworldwar.org/search/world-records/england- 


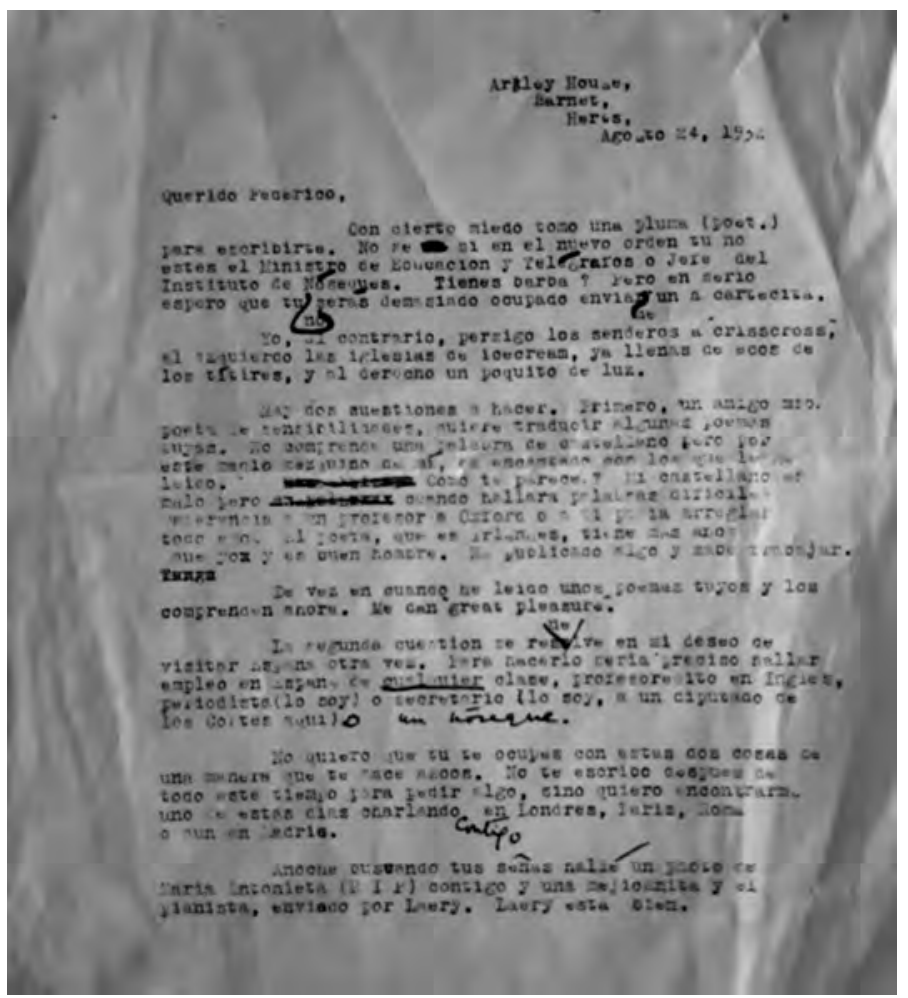

Querido Federico,

Con cierto miedo tomo una pluma (poet.) para escribirte. No se [word deleted] si en el nuevo orden tu no estes el Ministro de Educacion y Telégrafos o Jefe del Instituto de Nóseques. Tienes barba? Pero en serio espero que tu no serás demasiado ocupado enviarme una cartecita.

Yo, al contrario, persigo los senderos a "crisscross", al izquierdo las iglesias de icecream, ya llenas de ecos de los títeres, y al derecho un poquito de luz.

and-wales-deaths-1837-2007?firstname=william\&firstname_variants=true\&lastname=jones\&y earofdeath_offset=5\&o=lastname\&d=asc\&page $=\&$ http://www.ebooksread.com/authors-eng/ arthur-charles-fox-davies/armorial-families--a-directory-of-gentlemen-of-coat-armour-volume-1dxo/page-214-armorial-families--a-directory-of-gentlemen-of-coat-armour-volume-1-dxo.shtml: "Frank William Hackforth- Jones, Esq., J.P. co. Hertford, a Freeman of the City of London, b. 1863; m.1885; and has issue-Oliver Hackforth-Jones, Gentleman, b. i8yo[?] [m. and has issue]; Matthew Hackforth-Jones, Gentleman, M.A. Oxen., b. 1893 [m. 1924, Margaret, d. of Rev. Henry M. EliottBriscoe Drake]; Campbell Hackforth-Jones, Gentleman, b. 1904. Seat - Arkley House, Barnet, Herts”. 
Hay dos cuestiones a hacer. Primero, un amigo mio, poeta de sensibilidades, quiere traducir algunas poemas tuyas. No comprende una palabra de castellano pero por este medio mezquino de mí, es encantado con los que le he leido. [two words deleted]. Como te parece? Mi castellano es malo pero [two words deleted] cuando hallara palabras dificiles referencia a un profesor a Oxford o a ti para arreglar todo eso. El poeta, que es irlandes, tiene mas anos que yo y es buen hombre. Ha publicado algo y sabe trabajar. [word deleted]

De vez en cuando he leido unos poemas tuyos y los comprenden ahora. Me dan "great pleasure".

La segunda cuestion se [resolve] resuelve en mi deseo de visitar Espana otra vez. Para hacerlo seria preciso hallar empleo en Espana de cualquier clase, profesorcito en Ingles, periodista (lo soy) o secretario (lo soy, a un diputado de los Cortes aquí) o un nóseque.

No quiero que tu te ocupes con estas dos cosas de una manera que te hace ascos. No te escribo despues de todo este tiempo para pedir algo, sino quiero encontrarme uno de estos dias charlando contigo en Londres, Paris, Roma o aun en Madrid.

Anoche buscando tus señas hallé un photo de Maria Antonieta (RIP) ${ }^{6}$ contigo y una mejicanita y el pianista, enviado por Laery ${ }^{7}$. Laery esta bien.

${ }^{6}$ Actress, writer and political activist, María Antonieta (María Antonieta Valeria Rivas Mercado Castellanos Blair, Mexico City, 1900-Paris, 1931). As a patroness of the arts, María Antonieta sponsored the Orquesta Sinfónica de México as well as several Mexican artists and she created the experimental Teatro Ulises in Mexico City. She met García Lorca amd Campbell Hackforth-Jones in New York City: "temporalmente residente en Nueva York, separada de su marido inglés [Albert Edward] Blair y amante del escritor y político José Vasconselos [Calderón]" (Epistolario completo, 664, nota 704). Early in November 1929, García Lorca escribe a su familia desde New York: "Os mando una fotografía en la que estoy con María Antonieta Rivas, una mejicana millonaria, fundadora de la revista Contemporáneos y el teatro "Ulises" de México, gran amiga mía, de una muchacha hindú, bailarina que es una preciosidad, y de un pianista de Hawaii, muy bueno, que ha tenido gran éxito en New York. Son tres raros, desde luego, pero ingteligentes y muy artistas los tres. La foto es de la Universidad de Columbia” (Epistolario completo, 664. En la página 665, reproducción de la foto). María Antonieta Rivas commited suicide in Notre Dame Cathedral in París en February 1931. In a letter from Madrid (February-March 1931) to his family, García Lorca writes: "Os rogaría, si me pudieses encontrar los retratos de mi pobre amiga María Antonieta, me los enviarais, ya que tengo una gran gana de siquiera tener este recuerdo en mi estudio de un de mis mejores amigas y de una de las mujeres más inteligentes que he conocido" (Epistolario completo, 706). In 1982, Carlos Saura directed the film Antonieta, based on the novel of Andrés Henestrosa (Oaxaca, 1906-Mexico City, 2008), a novel based on the life of María Antonieta Rivas. The year 2010 saw the premiere of the opera Antonieta by the prolific Mexican composer Federico Ibarra Groth (b. Mexico City, 1946) with libretto by Verónica Musalem also based on the life of María Antonieta Rivas. In the archives of the Centro Federico García Lorca we find a unpublished letter (December 1929) from María Antonieta to García Lorca (reference number 853 in Christian de Paepe).

7 ¿Laery = Larry? Andrew A. Anderson writes that in New York, "Con un compañero, Larry, [Hackforth-Jones] habia alquilado un amplio cuarto en la calle 53 este” (see Anderson, 2013: 199, 201). 


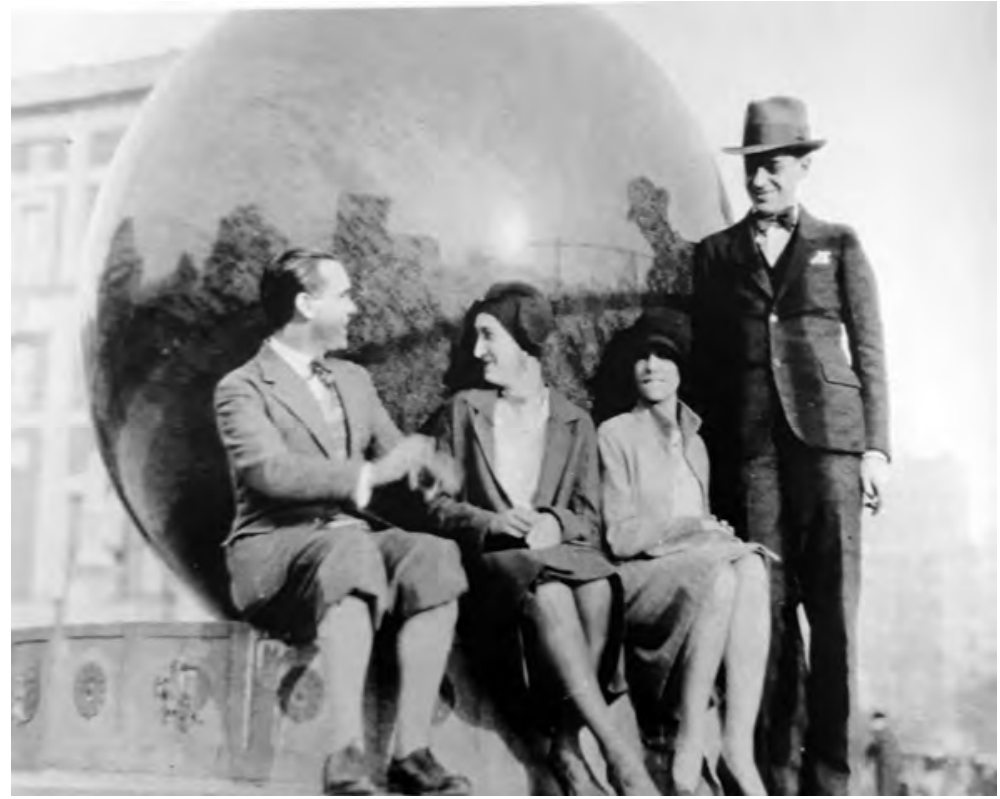

Federico García Lorca, María Antonieta Rivas, with unidentified dancer and pianist.

Photograph taken at the sundial on the campus of Columbia University, 1929. The16-ton sphere was removed in 1949.
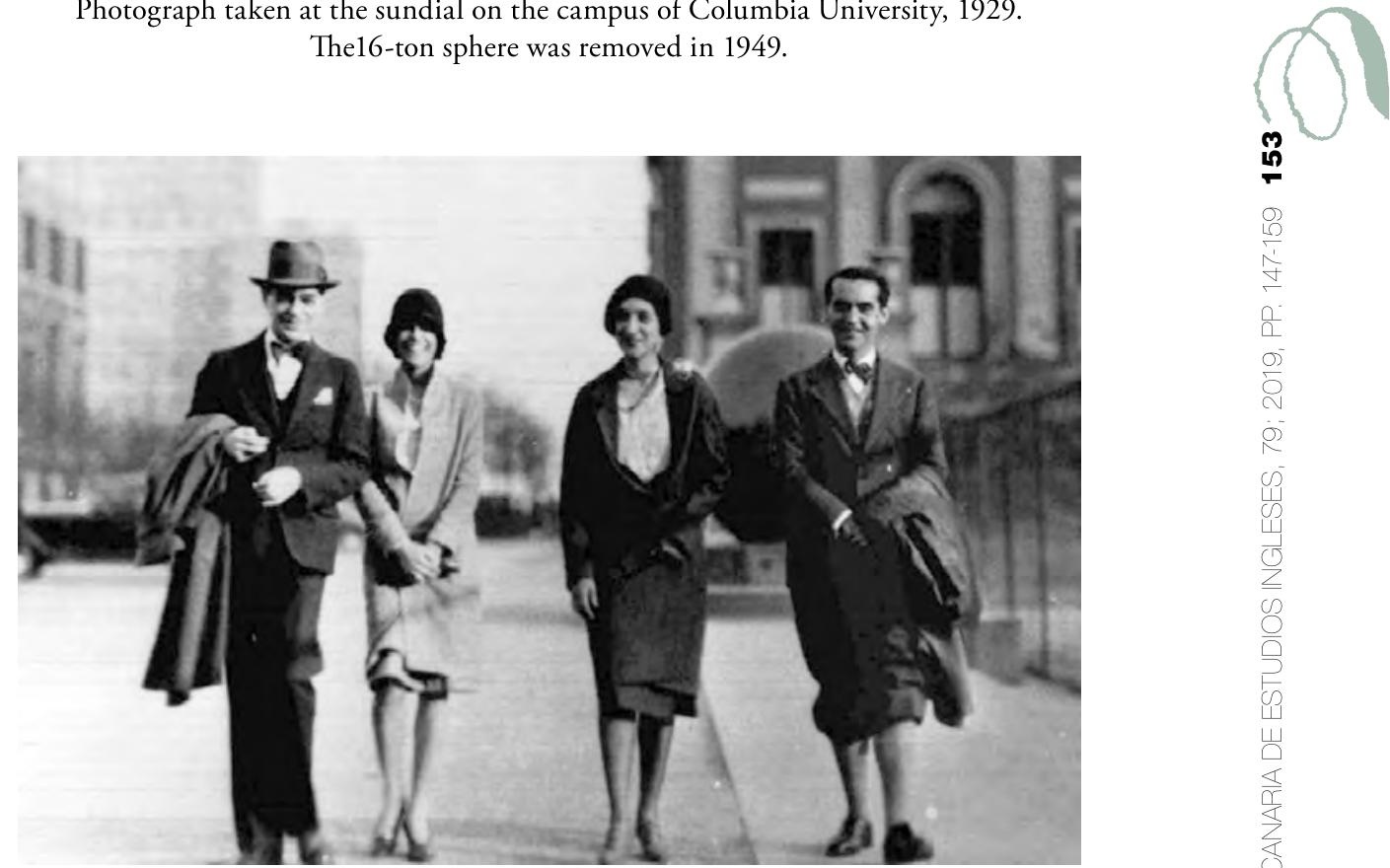

The same group, Federico García Lorca, Antonieta Rivas and the unidentified dancer and pianist. Columbia University, 1929. 


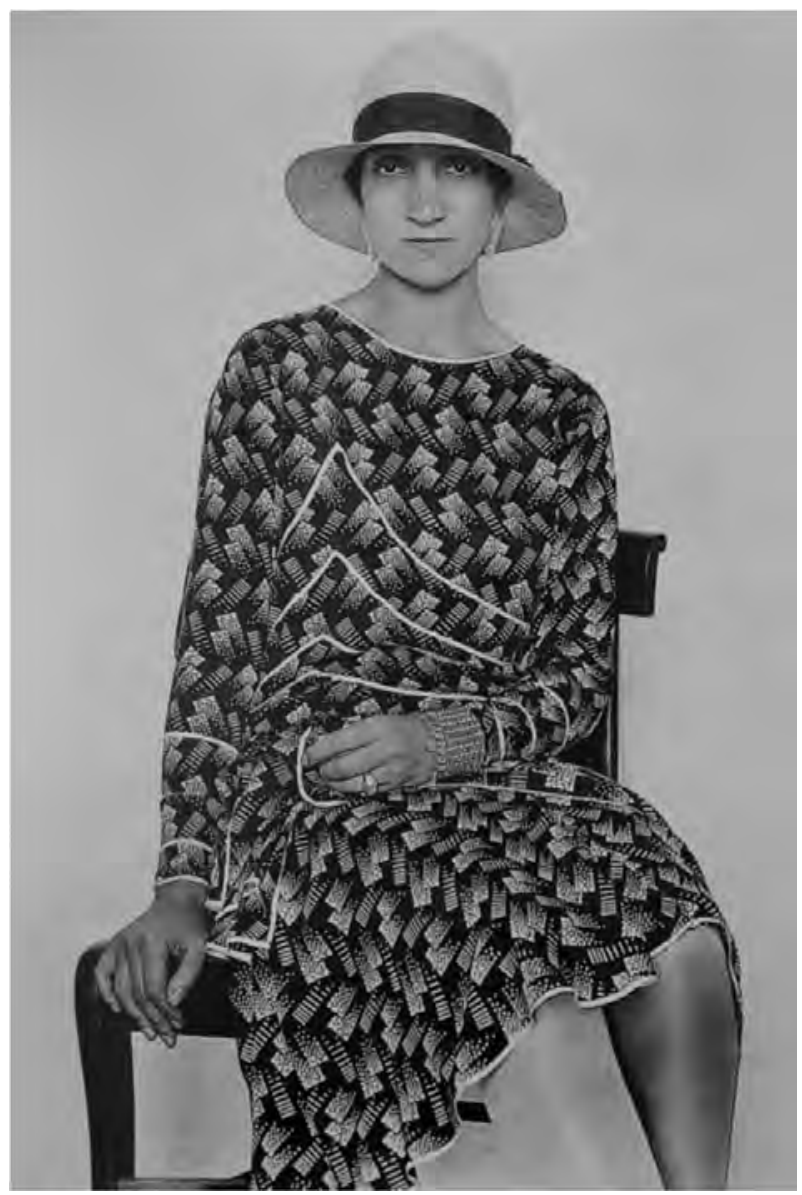

María Antonieta Valeria Rivas Mercado Castellanos Blair. Campbell Hackforth-Jones sent her a Christmas greeting which is housed in the archives of the Centro Federico Lorca (reference 464 in Christian de Paepe, 236). 


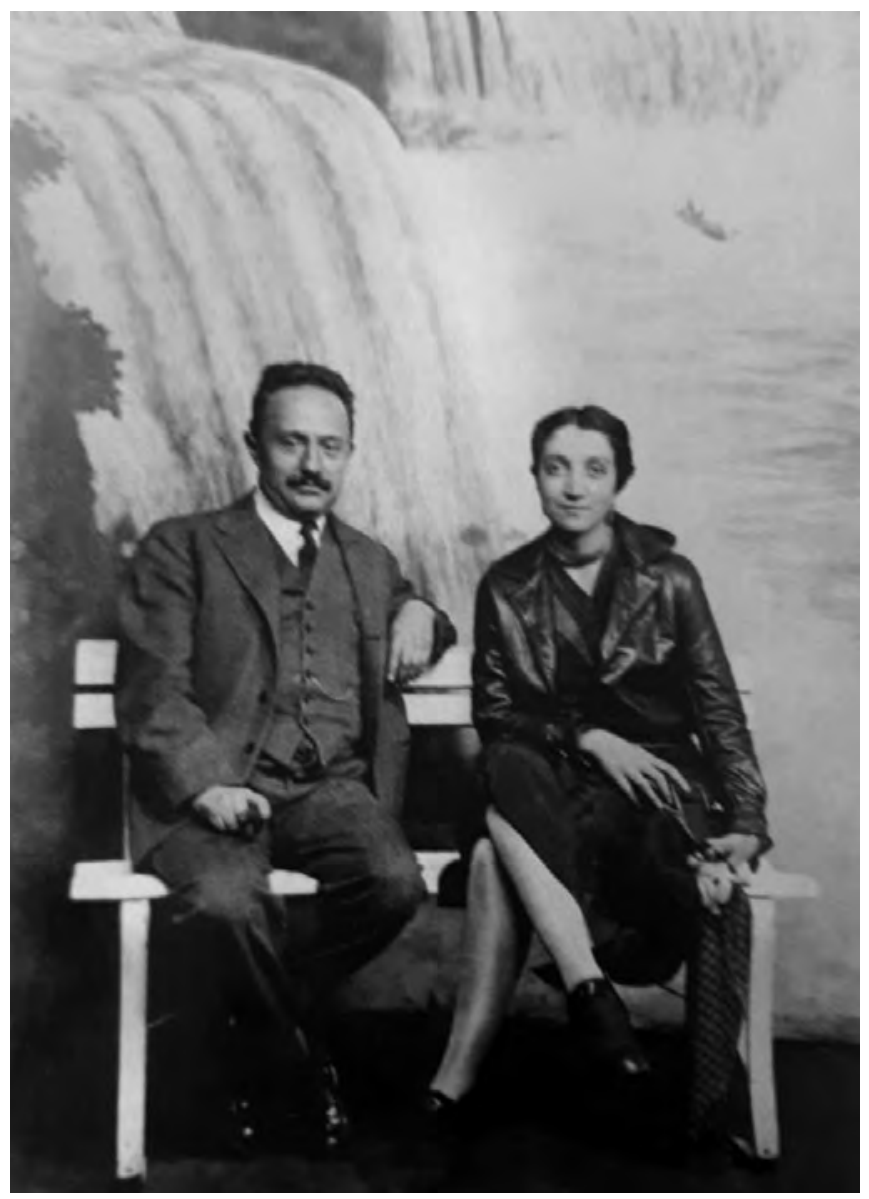




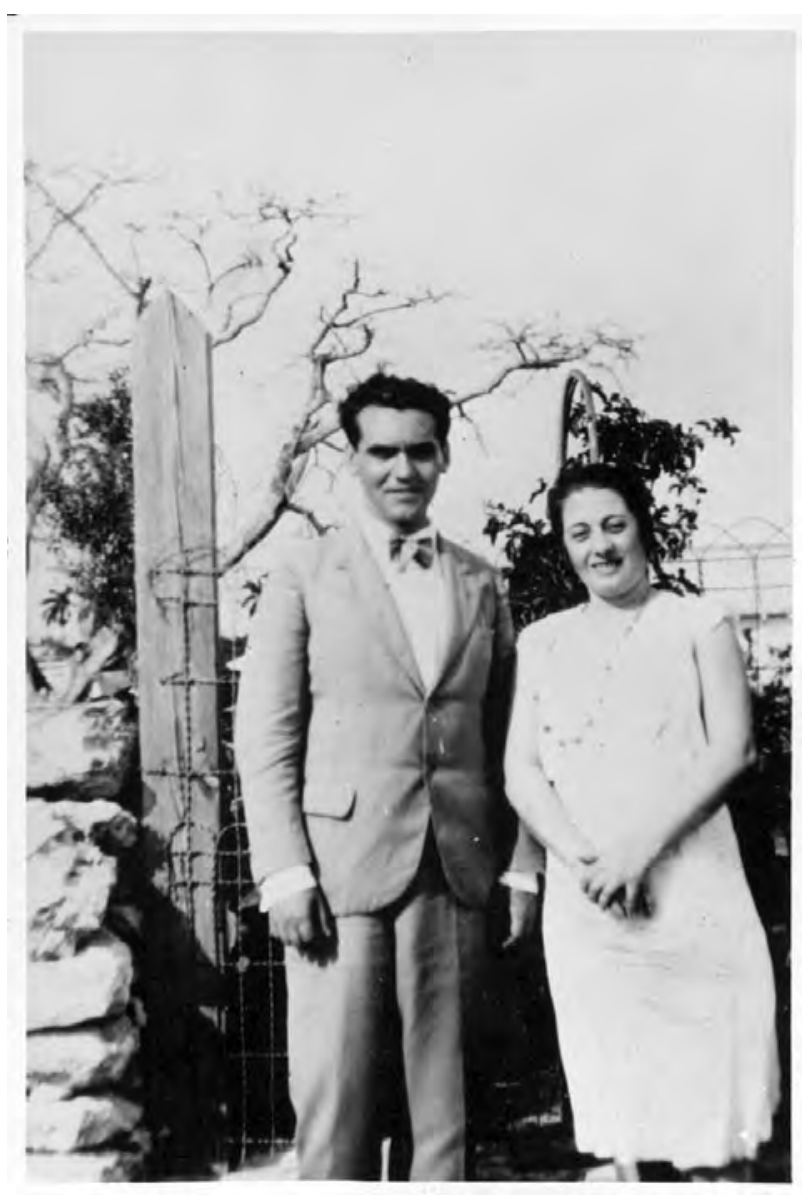

Photograph of Federico García Lorca con María Muñoz Quevedo, Cuba, Spring 1930. Lorca’s trip to Cuba came at the end of his 1929-1930 visit to the New World. María Muñoz Portal de Quevedo (A Coruña, 1886-La Habana, 1947) studied with Manuel de Falla in Madrid. In Cuba, she was a well-known pianist, choral director and music teacher. She and her husband Antonio Quevedo (Madrid, 1888-La Habana, 1977) had arrived in Cuba in 1919 and were frequently García Lorca's hosts in La Habana during the Spring of 1930. In La Habana, the Quevedos founded the Conservatorio de Música Bach, the Sociedad Coral de La Habana, the music magazine Musicalia, and in 1930 the Sociedad Contemporanea (Sección Cubana de la International Contemporary Music). Photograph reproduced by permission of the Residencia de Estudiantes, Madrid. 

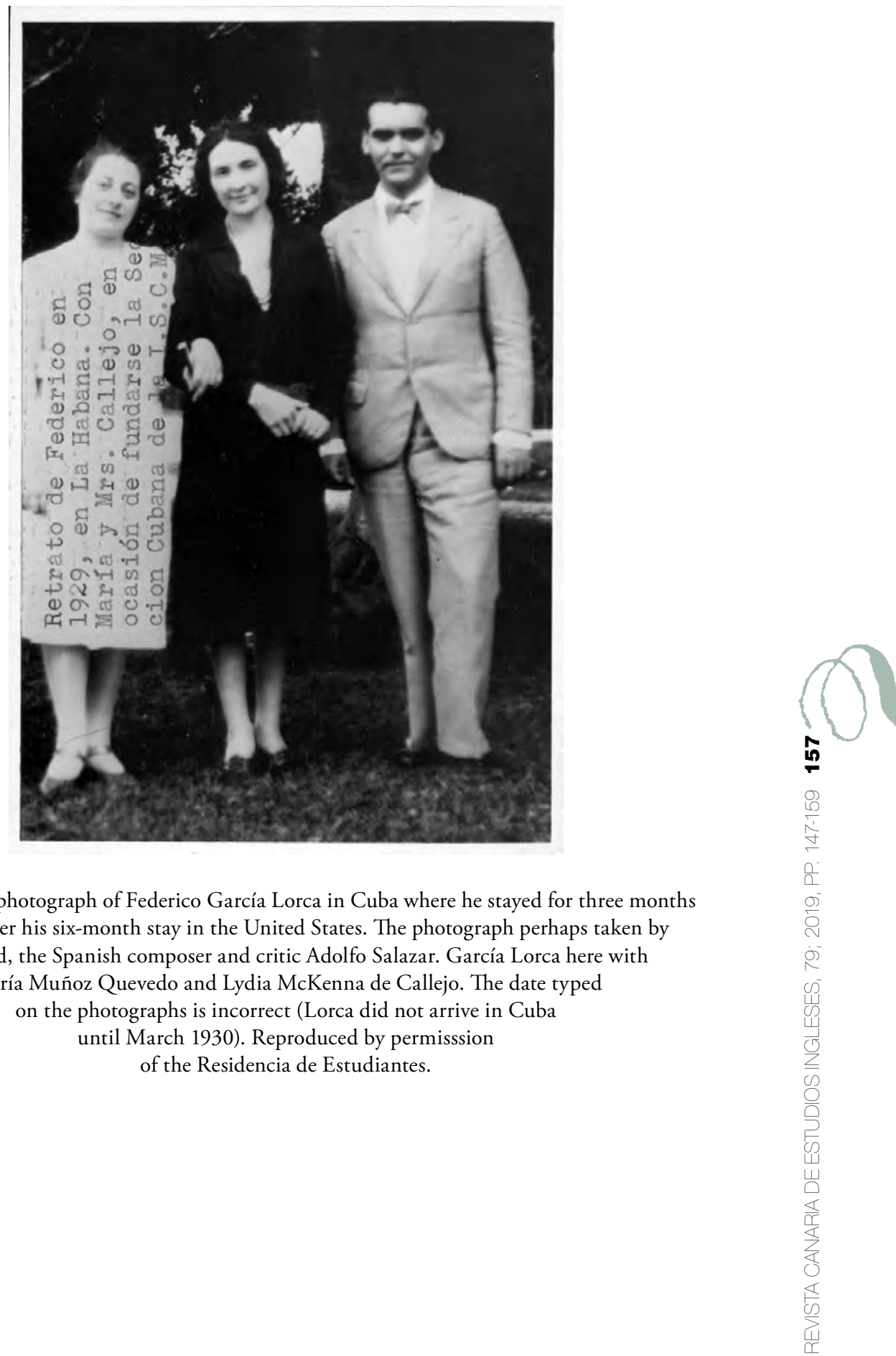


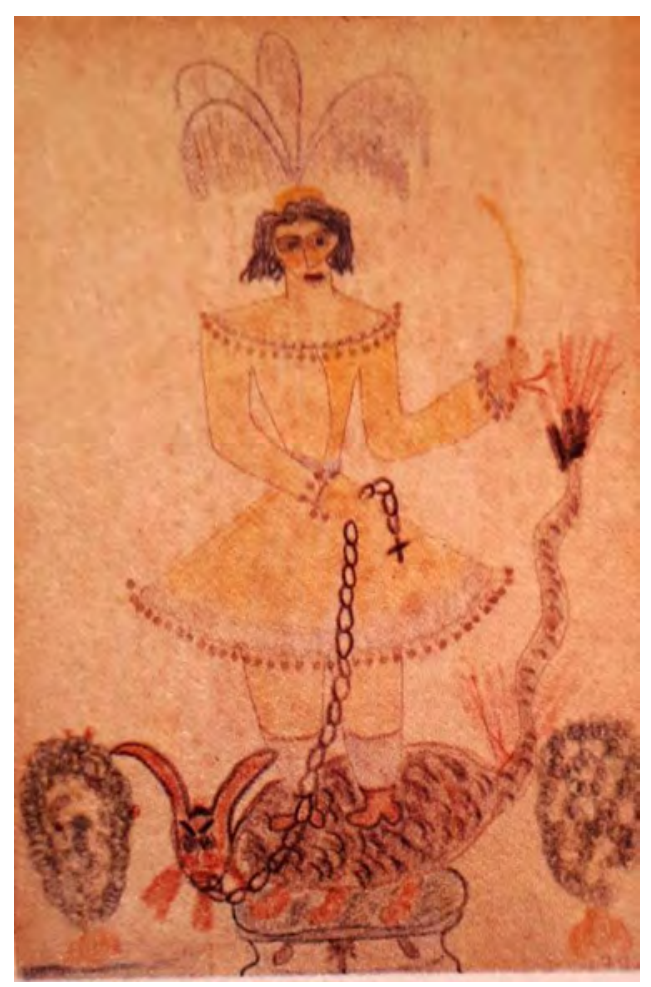

Drawing in ink and colored pencils given to Campbell Hackforth-Jones by Federico García Lorca $(480 \times 310 \mathrm{~mm})$.

On the back of the drawing, typewritten: "This drawing was executed by Federico García Lorca in Granada, Christmas 1927 as a present for me. It represents St. George and the Dragon, as he explained. The initials F.G.L. were added by me at some time or other. This drawing should be taken care of as it will, I believe, to be of great interest to those who are interested in his poetry, as much perhaps as some other people might be interested in any drawings by any well-known poet. Also this picture may in time to come have a money value: therefore do not let it be destroyed in case posterity wants to look at it. I think F.G.L. was very much aware of posterity and would have liked this to survive. It is as much him as his poetry. Cambridge / Arkley, 6 Sept. 1939”.

[Hand signed:] Campbell Hackforth-Jones. ${ }^{8}$

Reviews sent to author: 14 July 2019 Revised paper accepted for publication: 18 September 2019

${ }^{8}$ Cited in Mario Hernández, number 96. 


\section{WORKS CONSULTED}

Anderson, Andrew A. (ed.) América en un poeta. Los viajes de Federico García Lorca al nuevo mundo y la repercusión de su obra en la literatura americana. Sevilla: Universidad Internacional de Andalucía/Fundación Focus-Abengoa, 1999.

Anderson, Andrew A. "Una amistad inglesa de García Lorca” in Ínsula (462, XL, 1985: 3-4).

Anderson, Andrew A. "In Harlem with Campbell Hackforth-Jones." In Christopher Maurer \& Andrew A. Anderson. Federico García Lorca en Nueva York y La Habana. Cartas y recuerdos. Galaxia Gutenberg/Círculo de Lectores, 2013: 199-200.

García Lorca, Federico. Epistolario completo. Andrew A. Anderson \& Christopher Maurer, eds. Madrid: Cátedra, 1997.

García Lorca, Federico. Obras Completas. I. Poesía. Miguel García Posada, ed. Valencia/Barcelona: Galaxia Guntenberg, 1996.

Gibson, Ian. Federico Garcia Lorca. A Life. New York: Pantheon Books, 1989.

Gibson, Ian. Federico García Lorca. 1. De Fuente Vaqueros a Nueva York. 1898-1929. Barcelona: Grijalbo, 1985.

Hernández, Mario. Libro de dibujos de Federico García Lorca. Madrid: Tabapress/Fundación Federico García Lorca, 1990.

Maurer, Christopher \& Andrew A. Anderson. Federico Garcia Lorca en Nueva York y La Habana. Cartas y recuerdos. Barcelona: Galaxia Gutenberg, 2013.

Paepe, Christian de (dir.) Catálogo general de los fondos documentales de la Funcadión Federico García Lorca. Vol. vi. Catálogo de la Correspondencia a Federico García Lorca. Madrid: Consejería de Cultura de la Junta de Andalucía/Fundación Federico García Lorca, 2003. 
